\title{
Evaluation of Antioxidant and Cytotoxic Activities of Aerial Parts of Adiantum capillus-veneris L. Growing in Bangladesh
}

\author{
Suvash Chandra Roy ${ }^{1}$, B. K. Sajeeb ${ }^{2}$, Md. Abdul Muhit ${ }^{3}$ and Sitesh C. Bachar ${ }^{4}$ \\ ${ }^{1}$ Department of Pharmacology, Institute of Applied Health Sciences, University of Science and Technology \\ Chittagong, Chittagong-4202, Bangladesh \\ ${ }^{2}$ Department of Pharmaceutical Technology, Faculty of Pharmacy, University of Dhaka \\ Dhaka-1000, Bangladesh \\ ${ }^{3}$ Department of Clinical Pharmacy and Pharmacology, Faculty of Pharmacy, University of Dhaka \\ Dhaka-1000, Bangladesh \\ ${ }^{4}$ Department of Pharmacy, Faculty of Pharmacy, University of Dhaka, Dhaka-1000, Bangladesh
}

(Received: April 2, 2019; Accepted: June 20, 2019; Published (Web): October 5, 2019)

\begin{abstract}
The present study evaluated the antioxidant and cytotoxic activities of methanolic extract of aerial parts of Adiantum capillus-veneris L. and its different solvent fractions. The in vitro antioxidant activity was assessed by using 2,2'-diphenyl-1-picrylhydrazyl (DPPH) radicals. The analysis revealed that ethyl acetate soluble fraction had the highest DPPH radicals scavenging property with $\mathrm{IC}_{50}$ value of $1.05 \mu \mathrm{g} / \mathrm{ml}$ as compared to positive control ascorbic acid $\left(\mathrm{IC}_{50}=1.34 \mu \mathrm{g} / \mathrm{ml}\right)$. In addition, ex vivo cytotoxicity assay of $A$. capillus-veneris $\mathrm{L}$. extract and its different fractions were performed against HELA cells line where 5-Fluorouracil was used as positive control. The result demonstrated that ethyl acetate and n-hexane soluble fractions showed prominent cytotoxicity with $\mathrm{IC}_{50}$ value of $5.68 \mu \mathrm{g} / \mathrm{ml}$ and $17.15 \mu \mathrm{g} / \mathrm{ml}$, respectively. The study affirmed that superior antioxidant and cytotoxic activities were shown by ethyl acetate soluble fraction of methanolic extract of aerial parts of A. capillus-veneris L. growing in Bangladesh which indicate the presence of bioactive phytoconstituents in the extractives.
\end{abstract}

Key words: Antioxidant, cytotoxicity, Adiantum capillus-veneris L., fractionation, bioactivity.

\section{INTRODUCTION}

Adiantum capillus-veneris L. (A. capillus-veneris L.) belongs to the family Pteridaceae, is a perennial fern located worldwide especially in Mexico, warmer part of America, western Himalaya, southern part of India, and other tropical or subtropical regions. ${ }^{1,2}$ The genus Adiantum has 250 species and most of them are used as traditional medicines to treat cold, fever, bronchial disorder, jaundice, hepatitis, rheumatic fever, skin rashes, tumors of spleen, liver, and other viscera by the people of India, China, Pakistan, and Bangladesh. ${ }^{3-6}$ In Indian and Bangladeshi folk medicine, it has a diverse role in healing bronchitis, jaundice, kidney dysfunction, dandruff, increase lactation, parasitic infection, and general cure all. ${ }^{7-9}$

Correspondence to: Sitesh C Bachar

Email: bacharsc@du.ac.bd

Contact: +8801552356315

Dhaka Univ. J. Pharm. Sci. 18(2): 217-222, 2019 (December)

DOI: https://doi.org/10.3329/dujps.v18i2.43264
Previous phytochemical analyses reported that $A$. capillus-veneris L. is a prominent source of triterpenoid and flavonoids derivatives like quercetin, quercetin-3-o-glucoside, quercetin-3-o-rutinoside, isoadiantone, isoadiantol-B, 3-methoxy-4hydroxyfilicane, and 3,4-dihydroxyfilicane, etc. ${ }^{9}$ In addition, other bioactive phytoconstituents like phenolics, sterols, quinic acids, shikimic acids, ketones, diols, esters of hydroxycinnamic acid, etc. have been separated from A. capillus-veneris L. $^{10}$ Because of these bioactive compounds, A. capillusveneris $\mathrm{L}$. performs anti-inflammatory, antidiarrheal, antispasmodic, antimicrobial, analgesic, antinociceptive, antidiabetic, agglutinating, antiviral, hypoglycemic, antifungal, and detoxifying effects. ${ }^{11-14}$ A study revealed that methanolic extract of $A$. capillus-veneris L. leaf had pronounced analgesic, 
anti-inflammatory and hypoglycemic effects in Swiss Albino mice. ${ }^{14,15}$ Ethnopharmacological investigation among tribal people specially chakma, marma, and tanchangya of Khagrachchari district, Bangladesh found that local traditional practitioners use aerial parts of A. capillus-veneris $\mathrm{L}$. for healing skin problems like rashes, psoriasis, dermatitis, and different skin strains. ${ }^{16}$ The traditional practitioners dispensed different liquid or semisolid preparations of A. capillus-veneris $\mathrm{L}$. to tribal people for getting cure of skin lesion and rashes. In addition, Nilforoushzadeh et al. revealed that methanolic extract of A. capillus-veneris L. had wound healing effects of human umbilical vein endothelial cells and normal human dermal fibroblast line. ${ }^{17}$

The recent study evaluates the in vitro antioxidant and ex vivo cytotoxic activities of methanolic extract of aerial parts of A. capillus-veneris L. and its different solvent fractions. According to Wahab et al., antioxidant activity of any bioactive phytoconstituent is conducted with cytotoxic effects through reactive oxygen species (ROS) inhibition. ${ }^{18}$ Therefore, a qualitative correlation was made between antioxidant and cytotoxic activities of methanolic extract of A. capillus-veneris L. and its solvent fractions.

\section{MATERIALS AND METHODS}

Plant material. The aerial parts of A. capillusveneris $L$. were collected from Matiranga and Panchchari upzilas of Khagrachchari district, Bangladesh in the month of June and November 2017. A voucher specimen of A. capillus-veneris $\mathrm{L}$. with accession number of DACB-45943 has been deposited in Bangladesh National Herbarium, Dhaka, Bangladesh. The green aerial parts were then dried under shade, blended to powder and stored in air tight container.

Chemicals and instruments. Ascorbic acid (Merck, India), 2,2'-diphenyl-1-picrylhydrazyl (Merck, Germany), gentamicin, trypsin, HELA cell, DME medium, $10 \%$ fetal bovine serum were purchased from authorized suppliers. 5-Fluorouracil was gifted by Beximco Pharmaceuticals Limited,
Bangladesh. The cytotoxic activity was performed with the help of biological biosafety cabinet (NU400E, Nuaire, USA), $\mathrm{CO}_{2}$ incubator (Nuaire, USA), trinocular microscope with camera (Olympus, Japan), and hemocytometer (Nexcelom, USA). All instruments and chemicals were handled with care under safety environment.

\section{Extraction and fractionation of $A$. capillus-veneris $\mathbf{L}$.}

Air dried and powdered aerial parts of A. capillusveneris $\mathrm{L} .(1000 \mathrm{~g})$ were macerated with methanol at ambient temperature for $48 \mathrm{~h}$ with intermittent shaking and this process was repeated thrice. The combined methanolic extract was filtered and concentrated using rotary evaporator to obtain oily residue of $88.08 \mathrm{~g}$. This oily residue $(88.08 \mathrm{~g})$ was mixed with $250 \mathrm{ml}$ of aqueous methanol (90:10). Then the preparation was subjected to fractionation with $250 \mathrm{ml}$ of each $\mathrm{n}$-hexane, chloroform, and ethyl acetate, respectively to yield n-hexane $(21.47 \mathrm{~g})$, chloroform (19.60 g), ethyl acetate $(15.33 \mathrm{~g})$, and aqueous methanol (18.86 g) soluble fractions. The methanolic extract along with all fractions were subjected to antioxidant and cytotoxicity analyses.

\section{Determination of in vitro antioxidant activity of $A$. capillus-veneris $\mathbf{L}$.}

The antioxidant or free radicals scavenging activity of $A$. capillus-veneris $\mathrm{L}$. was carried out with 2,2'-diphenyl-1-picrylhydrazyl (DPPH) free radicals by using the method described by Brand et al. ${ }^{19}$ During this analysis, ascorbic acid (positive control) of $5,20,50,100,250,500$, and $1000 \mu \mathrm{g} / \mathrm{ml}$ along with DPPH of $20 \mu \mathrm{g} / \mathrm{ml}$ were prepared in methanol and were kept in light proof box. Different concentrations $(5,20,50,100,250$, and $500 \mu \mathrm{g} / \mathrm{ml})$ of each of methanolic extract and its soluble fractions were obtained in methanol. Then, $2 \mathrm{ml}$ of each of prepared sample (methanolic extract, soluble fractions or ascorbic acid) from different concentrations was mixed with $2 \mathrm{ml}$ of DPPH solution $(20 \mu \mathrm{g} / \mathrm{ml})$. The mixture was incubated in a dark place for 30 minutes and was analyzed by 
UV/Vis spectrophotometer (Shimadzu, Japan) at $\lambda \max$ of $517 \mathrm{~nm}$.
Inhibition of free DPPH radicals in percent (I \%) was calculated by using the following equation:

$$
\text { Percent of inhibition }(\mathrm{I} \%)=\left[\frac{\text { Absorbance }(\text { control })-\text { Absorbance (sample) }}{\text { Absorbance }(\text { control })}\right] \times 100 \%
$$

The free radicals scavenging activity was expressed as $\mathrm{IC}_{50}(\mu \mathrm{g} / \mathrm{ml})$ which is defined as the concentration of sample necessary to scavenge $50 \%$ of free DPPH radicals. The $\mathrm{IC}_{50}$ was calculated by a regression equation generated by plotting percentage of inhibition (I \%) against the respective concentrations of the samples.

\section{Ex vivo cytotoxic activity of $A$. capillus-veneris $\mathbf{L}$.}

Cytotoxicity of methanolic extract of aerial parts of A. capillus-veneris L. and its different soluble fractions were examined in Centre for Advanced Research in Sciences (CARS), Dhaka, Bangladesh against HELA cell line where 5-Fluorouracil was used as positive control. HELA, a human cervical carcinoma cell line was maintained in DMEM (Dulbecco's modified eagles' medium) containing 1 $\%$ penicillin-streptomycin (1:1), $0.2 \%$ gentamycin, and $10 \%$ fetal bovine serum (FBS). HELA cells were seeded onto 96 -well plate with $2 \times 10^{4}$ cells per well $(100 \mu \mathrm{l})$ and incubated at $37{ }^{\circ} \mathrm{C}$ under a humidified atmosphere of $5 \%$ of $\mathrm{CO}_{2}$ for $24 \mathrm{~h}$. Next day, the serum free medium containing $25 \mu \mathrm{l}$ of autoclaved crude extract and fractions were added to cell medium in test wells. In addition, the cell medium in control wells was changed to serum free medium containing an equivalent volume of dimethyl sulfoxide (DMSO). Cytotoxic activity was examined after $48 \mathrm{~h}$ of incubation using cell counting kit-8 (CCK-8), a nonradioactive colorimetric cell proliferation and cytotoxic assay kit (Sigma Aldrich, USA). Duplicated wells were used for each sample.

\section{RESULTS AND DISCUSSION}

In the current analysis, antioxidant or free radicals scavenging activity of A. capillus-veneris L. was determined by using free DPPH radicals for methanolic extract of aerial parts of A. capillus- veneris L. and its different soluble fractions (nhexane, chloroform, and ethyl acetate). Results obtained from the analysis revealed that different fractions including the methanolic extract exhibited significant inhibition of free DPPH radicals. The free radicals scavenging assay demonstrated that ethyl acetate fraction performed the highest percent of inhibition than ascorbic acid (positive control) (Table 1). In addition, the $\mathrm{IC}_{50}$ value of ethyl acetate fraction $\left(\mathrm{IC}_{50}=1.05 \mu \mathrm{g} / \mathrm{ml}\right)$ was greater than ascorbic acid $\left(\mathrm{IC}_{50}=1.34 \mu \mathrm{g} / \mathrm{ml}\right)$. The $\mathrm{n}$-hexane and chloroform soluble fractions as well as the methanolic extract demonstrated potential free radicals scavenging activity.

In general, plants having phenolics and flavonoids are capable of scavenging free oxidative radicals because these molecules are able to donate hydrogen atom. ${ }^{20}$ Herlina et $a l .{ }^{21}$ stated that semipolar proton donating phenolics and flavonoids are more extracted in semipolar ethyl acetate solvent. Several Adiantum L. species including $A$. capillus-veneris L., $A$. lunulatum Burm.f., A. philippenase L., $A$. flabellulatum L., A. pedatum L., and A. tenarum L. contain significant amount of bioactive phytoconstituents like phenolics, flavonoids, triterpenoids, and sterols, etc. ${ }^{10}$ Beside this, Naema $e t$ al. quantified total phenolics and flavonoids in $A$. capillus-veneris $\mathrm{L}$. which evidenced the presence of antioxidant activity in methanolic extract of $A$. capillus-veneris L. ${ }^{22}$ These bioactive molecules have drawn more attention because of their relation to prevent cancer, skin rashes, inflammation, and coronary heart disorders. ${ }^{23}$

In addition to free radicals scavenging analysis, cytotoxic activity of methanolic extract of $A$. capillus-veneris $\mathrm{L}$. and its different soluble fractions were performed against HELA cell line. The results (Table 2) demonstrated that, A. capillus-veneris L. extract and its different fractions exhibited potential 
cytotoxicity against HELA cells. The methanol extract and its n-hexane, chloroform, and ethyl acetate soluble fractions exerted $\mathrm{IC}_{50}$ value of 52.53 , $17.15,32.35$, and $5.68 \mu \mathrm{g} / \mathrm{ml}$, respectively as compared to $0.87 \mu \mathrm{g} / \mathrm{ml}$ showed by 5 -Fluorouracil (positive control). A recent study conducted by Reshi et al. found that crude aqueous extract of A. capillusveneris $\mathrm{L}$. had $\mathrm{IC}_{50}$ value of $36.96 \mu \mathrm{g} / \mathrm{ml}$ against HELA cell line. ${ }^{24}$ Here, $\mathrm{IC}_{50}(\mu \mathrm{g} / \mathrm{ml})$ value indicates the concentration of sample with capability to inhibit $50 \%$ proliferation of cancerous cells.

Table 1. Antioxidant activity of methanolic extract of aerial parts of A. capillus-veneris $\mathbf{L}$. and its different soluble fractions.

\begin{tabular}{lccccccc}
\hline Sample & \multicolumn{9}{c}{ Percent of inhibition at different concentrations $(\mu \mathrm{g} / \mathrm{ml})$} & \multicolumn{1}{c}{$\mathrm{IC}_{50}(\mu \mathrm{g} / \mathrm{ml})$} \\
\hline & 5 & 20 & 50 & 100 & 250 & 500 & \\
\hline $\begin{array}{l}\text { Ascorbic acid } \\
\text { (Positive control) }\end{array}$ & $51.3 \pm 1.2$ & $63.8 \pm 0.7$ & $77.5 \pm 2.3$ & $85.8 \pm 1.2$ & $92.1 \pm 1.2$ & $92.7 \pm 1.3$ & 1.34 \\
Methanolic extract & $9.2 \pm 0.7$ & $17.4 \pm 1.1$ & $39.6 \pm 1.9$ & $63.8 \pm 2.9$ & $73.2 \pm 0.4$ & $74.4 \pm 0.9$ & 4.37 \\
n-Hexane fraction & $5.5 \pm 0.8$ & $23.7 \pm 1.6$ & $33.1 \pm 1.5$ & $57.3 \pm 0.8$ & $64.1 \pm 1.1$ & $68.4 \pm 1.1$ & 4.69 \\
Chloroform fraction & $26.2 \pm 1.2$ & $48.4 \pm 1.9$ & $64.4 \pm 0.7$ & $78.1 \pm 0.5$ & $84.3 \pm 1.2$ & $86.3 \pm 1.2$ & 3.08 \\
Ethyl acetate fraction & $54.1 \pm 1.9$ & $65.4 \pm 2.1$ & $78.4 \pm 2.1$ & $87.7 \pm 1.2$ & $92.7 \pm 1.8$ & $93.1 \pm 0.7$ & 1.05 \\
\hline
\end{tabular}

Table 2. Cytotoxic activity of methanolic extract of aerial parts of $A$. capillus-veneris $\mathbf{L}$. and its different soluble fractions.

\begin{tabular}{lccc}
\hline Sample & $\begin{array}{c}\text { Concentration } \\
(\mu \mathrm{g} / \mathrm{ml})\end{array}$ & $\begin{array}{c}\text { Percent of inhibition against } \\
\text { HELA cell line }\end{array}$ & $\begin{array}{c}\mathrm{IC}_{50} \text { value } \\
(\mu \mathrm{g} / \mathrm{ml})\end{array}$ \\
\hline \multirow{3}{*}{ 5-Fluorouracil } & 20 & 75.7 & \\
& 50 & 91.5 & \\
& 100 & 95.7 & \\
Methanolic extract & 20 & 19.3 & 52.53 \\
& 50 & 52.2 & \\
n-Hexane fraction & 100 & 67.3 & \\
& 20 & 51.3 & \\
Chloroform fraction & 50 & 77.4 & 32.35 \\
& 100 & 85.1 & \\
Ethyl acetate fraction & 20 & 33.7 & \\
& 50 & 68.2 & 5.68 \\
\hline
\end{tabular}

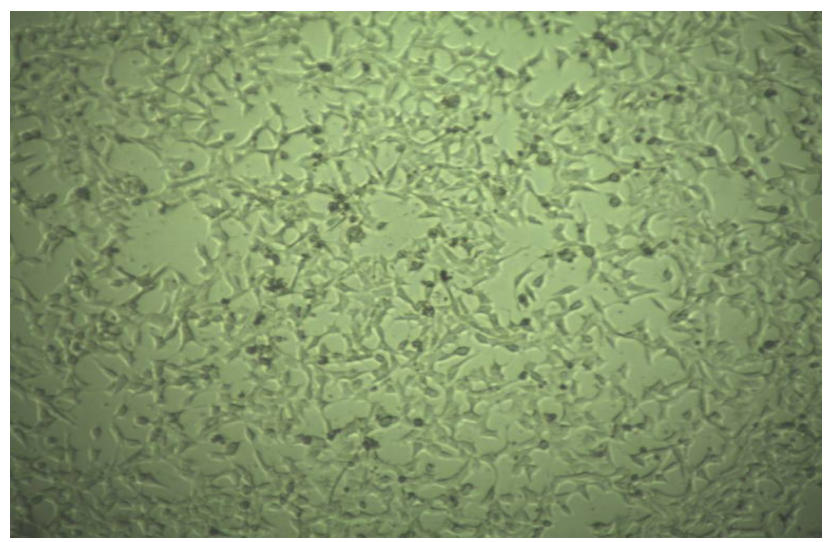

Figure 1. Cytotoxic activity of ethyl acetate soluble fraction of A. capillus-veneris L. under an inverted light microscope. 


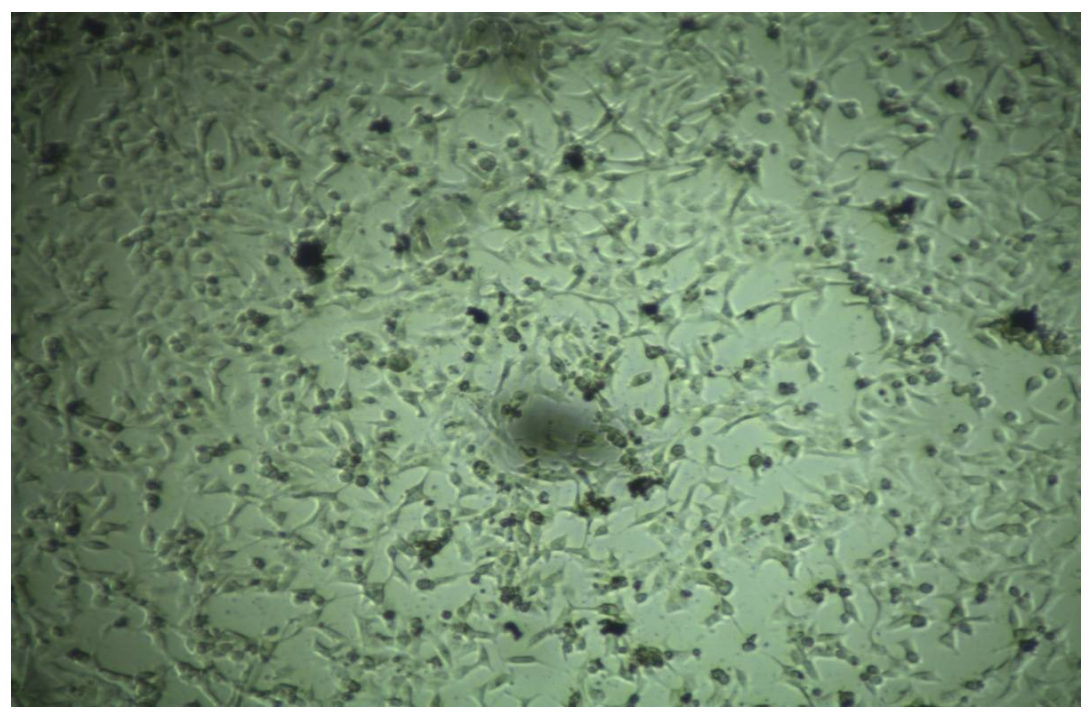

Figure 2. Cytotoxic activity of $\mathrm{n}$-hexane soluble fraction of A. capillus-veneris $\mathrm{L}$. under an inverted light microscope.

According to the American National Cancer Institute (ANCI), a promising anticancer product with significant cytotoxic effect should exerts an $\mathrm{IC}_{50}$ value less than $30 \mu \mathrm{g} / \mathrm{ml}^{25}$ The ethyl acetate and $\mathrm{n}$ hexane soluble fractions with $\mathrm{IC}_{50}$ of $5.68 \mu \mathrm{g} / \mathrm{ml}$ (Figure 1) and $17.15 \mu \mathrm{g} / \mathrm{ml}$ (Figure 2) can be considered as promising cytotoxic products. In agreement with Salae et $a l^{26}$, bioactive phytoconstituents like triterpinoids and flavonoids are responsible for cytotoxic effects of plant species. These phytoconstituents are highly extracted in ethyl acetate and n-hexane solvent. ${ }^{26}$ As a results, ethyl acetate and $n$-hexane soluble fractions of methanolic extract of A. capillus-veneris L. exhibited potential cytotoxicity against HELA cell lines.

\section{CONCLUSION}

The present study demonstrated that the aerial parts of A. capillus-veneris L. growing in Bangladesh had significant antioxidant and cytotoxic activities. The analyses were performed on methanolic extract of aerial parts of A. capillus-veneris L. along with its n-hexane, chloroform, and ethyl acetate soluble fractions. Solubility guided fractionation revealed that ethyl acetate soluble fraction had higher antioxidant $\left(\mathrm{IC}_{50}=1.05 \mu \mathrm{g} / \mathrm{ml}\right)$ and cytotoxic $\left(\mathrm{IC}_{50}=\right.$ $5.68 \mu \mathrm{g} / \mathrm{ml}$ ) activities than the other fractions. The relatively better bioactivity of $A$. capillus-veneris $\mathrm{L}$. growing in Bangladesh as compared to other countries like India and Libya suggested that the quality of soil and environmental conditions of Bangladesh might be facilitated the biosynthesis of active compounds in A. capillus-veneris L. The study will be great scientific evidences for ethnomedicinal uses of A. capillus-veneris $\mathrm{L}$. by the traditional practitioners in Bangladesh. Additional researches should be conducted to isolate and characterize the bioactive compounds and to elucidate the molecular mechanisms of the pleiotropic activities of $A$. capillus-veneris $\mathrm{L}$.

\section{ACKNOWLEDGEMENTS}

The authors are grateful to the authority of Centre for Advanced Research in Sciences (CARS), Dhaka, Bangladesh for assistance in the research work. Authors would also like to express gratitude to Dr. Md. Zakir Sultan, CARS, Dhaka, Bangladesh for his cordial support during the analytical works.

\section{REFERENCES}

1. Nakane, T., Maeda, Y. and Ebihara, H. 2002. Fern constituents: triterpenoids from Adiantum capillus-veneris. L. Chem. Pharm. Bull. 50, 1273-1275.

2. Reddy, B.U. 2010. Enumeration of antibacterial activity of few medicinal plants by bioassay method. J. Chem. 7, 1449-1453. 
3. Singh, M., Singh, N., Khare, P.B. and Rawat, A.K.S. 2008. Antimicrobial activity of some important Adiantum species used traditionally in indigenous systems of medicine. $J$. Ethnopharmacol. 115, 327-329.

4. Abbasi, A.M., Khan, M.A., Ahmad, M., Zafar, M., Jahan, S. and Sultana, S. 2010. Ethnopharmacological applications of medicinal plants to cure skin diseases and in folk cosmetics among the tribal communities of north-west frontier province. Pak. J. Ethnopharmacol. 128, 322-335.

5. Ahmad, I., Hussain, M., Ahmad, M.S.A., Ashraf, M.Y., Ahmad, R. and Ali, A. 2008. Spatio-temporal variations in physiochemical attributes of Adiantum capillus-veneris $\mathrm{L}$. from soone valley of salt range, Pakistan. Pak. J. Bot. 40, 1387-1398.

6. Christenhusz, M.J.M., Xian-Chun, Z. and Schneider, H. 2011. A linear sequence of extant families and genera of lycophytes and ferns. Phytotaxa 19, 47-54.

7. Mati, E. and de Boer, H. 2011. Ethnobotany and trade of medicinal plants in the gaysari market, kurdish autonomous region, Iraq. J. Ethnopharmacol. 133, 490-510.

8. Soeren, O., Martin, K., Shusmita, K., Shamim, H.T. and Hans, H. 2013. Traditional medicinal plants used for the treatment of diabetes in rural and urban areas of Dhaka, Bangladesh-an ethnobotanical survey. J. Ethnobiol. Ethnomed. 9, 43-51.

9. Ibraheim, Z.Z., Ahmed, A.S. and Gouda, Y.G. 2011. Phytochemical and biological studies of Adiantum capillusveneris L. Saudi Pharm. J. 19, 65-74.

10. Brahmachari, G., Mondal, S., Chatterjee, D. and Brahmachari, A.K. 2003. Phytochemicals and biological activities of Adiantum capillus species. J. Sci. Indus. Res. 62, 1119-1130.

11. Yuan, Q., Zhang, X., Liu, Z., Song, S., Xue, P., Wang, J. and Ruan, J. 2013. Ethanol extract of Adiantum capillus-veneris L. suppresses the production of inflammatory mediators by inhibiting NF-kB activation. J. Ethnopharmacol. 147, 603611.

12. Khalid, H.J., Waseem, H., Malik, H.M. and Anwarul, H.G. 2015. Antidiarrheal and antispasmodic activities of Adiantum capillus-veneris $\mathrm{L}$. are predominantly mediated through ATP-dependent $\mathrm{K}+$ channels activation. Bangladesh $J$. Pharmacol. 10, 222-229.

13. Ishaq, M.S., Hussain, M.M., Afridi, M.S., Ali, G., Khattak, M., Ahmad, S. and Shakirullah, M. 2014. In vitro phytochemical, antibacterial, and antifungal activities of leaf, stem, and root extracts of Adiantum capillus-veneris L. Sci. World J. 26, 97-103.

14. Aggarwal, B.B., Shishodia, S., Sandur, S.K., Pandey, M.K. and Sethi, G. 2006. Inflammation and cancer: how hot is the link? Biochem. Pharmacol. 72, 1605-1621.
15. Chowdhury, S., Poddar, S.K., Zaheen, S., Noor, F.A., Ahmed, N., Haque, S., Sukul, A., Sunjida, S.B., Mazumder, M.M.U. and Akbar, N. 2017. Phytochemical screening and evaluation of cytotoxic and hypoglycemic properties of Mangifera indica peels. Asian Pac. J. Trop. Biomed. 7, 49-52.

16. Sarder, N.U., Uddin, M.Z., Hassan, M.A. and Rahman, M.M. 2004. Preliminary ethnomedicinal plant survey in Khagrachari district, Bangladesh. Bangladesh J. Plant Taxon. 11, 39-48.

17. Nilforoushzadeh, M.A., Javanmard, S.H., Ghanadian, M., Asghari, G., Jaffary, F., Yakhdani, A.F., Dana, N. and Fatemi, S.A. 2014. The effects of Adiantum capillus-veneris L. on wound healing: an experimental in vitro evaluation. Int. J. Prev. Med. 5, 1261-1268.

18. Wahab, N.A., Ahdan, R., Aufa, Z.A., Kong, K.W., Johar, M.H., Shariffa, Z.M. and Ismaila, A. 2015. Nutritional values and bioactive components of underutilized vegetables consumed by indigenous people in Malaysia. J. Sci. Food. Agric. 95, 2704-2711.

19. Brand, W.W., Cuvelier, H.E. and Berset, C. 1995. Use of a free radical method to evaluate antioxidant activity. Int. J. Food Sci. Tech. 82, 25-30.

20. Fariba, S., Dehghn-Nudeh, G. and Mirtajaldini, M. 2009. Major flavonoids with antioxidant activity from Teucrium polium L. Food Chem. 112, 885-888.

21. Herlina, N., Riyanto, S., Martono, S. and Rohman, A. 2018. Antioxidant activities, phenolic and flavonoid contents of methanolic extract of Stelechocarpus burahol fruit and its fractions. Dhaka Univ. J. Pharm. Sci. 17, 153-159.

22. Naema, M.E.A., Salah, N.B., Mohammed, F.E. and Yusra, F.L. 2018. Determination of the total phenolic and flavonoid in various extracts of Adiantum capillus-veneris L., as well as their radical scavenging activity. Acta Sci. Microb. 1, 04-09.

23. Garcia, M.V., Crespo, I., Collado, P.S., Esteller, A., SanchezCampos S., Tunon, M.J. and Gonzalez-Gallego, J. 2007. The anti-inflammatory flavones quercetin and kaempferol cause inhibition of inducible nitric oxide synthase, cyclooxygenase2 and reactive $\mathrm{C}$-protein, and down regulation of the nuclear factor kappa-B pathway in chang liver cells. Eur. J. Pharmacol. 557, 221-229.

24. Reshi, I.A., Sarkar, T.K., Malik, H.U., Muhee, A. and Bhat, A.H. 2017. Evaluation of the cytotoxic activity of crude aqueous extracts of some medicinal plants of Kashmir. $J$. Cell Tissue Res. 17, 6047-6050.

25. Suffness, M. and Pezzuto, J.M. 1990. Methods in plant biochemistry: assays for bioactivity, academic press, London, pp. $71-133$.

26. Salae, A. and Boonnak, N. 2013. Obtusinones D and E, linear and angular fused dimeric icetexane diterpenoids from Premna obtusifolia roots. Tetrahedron Lett. 54, 1356-1359. 